\title{
Phytochemical characterisation and bioactive properties of Solanum sodomaeum L. fruits at two stages of maturation
}

\author{
INES OUERGHEMMI ${ }^{1,2}$, MOUNA BEN FARHAT ${ }^{3, *}$, HELA HARBEOUI ${ }^{1,2}$, MAJDI HAMMAMI ${ }^{1}$, \\ GHAITH HAMDAOUI ${ }^{4}$, BRAHIM MARZOUK ${ }^{1}$, MOUFIDA SAIDANE TOUNSI ${ }^{1}$
}

\author{
${ }^{1}$ Laboratory of Aromatic and Medicinal Plants \\ Centre of Biotechnology of Borj-Cedria \\ BP 901, Hammam-Lif 2050, Tunisia \\ ${ }^{2}$ Department of Biology \\ Faculty of Sciences of Bizerte, University of Carthage \\ Jarzouna, Bizerte, Tunisia \\ ${ }^{3}$ Laboratory of Extremophile Plants \\ Centre of Biotechnology of Borj-Cedria \\ BP 901, Hammam-Lif 2050, Tunisia \\ ${ }^{4}$ Unit of Support for Research and Technology Transfer \\ Technopole of Borj-Cedria \\ BP 901, Hammam-Lif 2050, Tunisia
}

*corresponding author: e-mail: mounabenfarhat@hotmail.fr

\section{Summary}

Introduction: Solanum sodomaeum L. has been observed to have several medicinal properties, in particular, in the treatment of several types of human skin cancer.

Objective: The influence of the maturation stage of S. sodomaeum fruits on the total lipid contents, fatty acid profiles, essential oil yields and compositions, as well as the antibacterial and antioxidant activities of the essential oils, was investigated.

Methods: The fatty acid and essential oil constituents were identified using gas chromatography (GC) and GC-mass spectrometry (GC-MS). The antioxidant properties of essential oil and vegetal oil were assessed using 1,1-diphenyl-2-picryl-hydrazyl (DPPH) scavenging and reducing power assays. The antibacterial ac- 
tivity of essential oil was tested using the disc diffusion assay for resistance in human pathogenic bacteria.

Results: Mature fruits showed higher total lipid content (17\%) and were characterised by polyunsaturated fatty acids $(53.87 \%)$, represented mainly by linoleic acid $(53.11 \%)$. Similar yields of essential oils were detected for immature $(0.43 \%)$ and mature $(0.45 \%)$ fruits. Tetrahydronaphthalene $(41.79 \%)$ was detected as the major essential oil component at the immature stage versus dihydrocoumarin pentane (18.27\%), hexadecanoic acid (17.43\%) and 2-undecanone (13.20\%) in mature fruits. The DPPH test showed that essential oils had better antioxidant properties; however, the vegetal oils showed better performance in the reducing power assay. Moreover, the essential oil of S. sodomaeum mature fruits was active against bacterial strains.

Conclusions: S. sodomaeum fruits could be a valuable source of natural antioxidants and antibacterial agents.

Key words: antibacterial activity, antioxidant activity, essential oils, fatty acids, fruit maturation, Solanum sodomaeum

Słowa kluczowe: aktywność antybakteryjna, aktywność antyoksydacyjna, olejki eteryczne, kwasy ttuszczowe, dojrzewanie owoców, Solanum sodomaeum

\section{INTRODUCTION}

The genus Solanum is widespread in temperate and tropical areas and includes about 1700 species. Species of the genus Solanum produce a class of useful biologically active secondary metabolites, the glycoalkaloids [1]. These nitrogen-containing steroidal glycosides have revealed antibiotic, antifungal, antimicrobial and antiviral properties [2] and show significant cytotoxicity against several human cancer cell lines and skin tumours [3]. Glycoalkaloids are toxic compounds at certain levels considering their role as plants' defensive allelochemicals against a number of pathogens and predators [4].

Among the numerous species of the genus, Solanum sodomaeum L. is common in Tunisia [5]. The fruits of S. sodomaeum are used in the treatment of external warts and eczema. The species is a source of solasodine, a raw material for the hemisynthesis of steroid hormones [5]. S. sodomaeum glycoalkaloids have been shown to be efficient in several types of human skin cancer therapies [6]. Steroidal glycosides extracted from the roots of the species exhibit antiproliferative activity in resistance to human promyelocytic leukaemia (HL-60) cells [7].

Previous investigations on S. sodomaeum have focussed on its alkaloids $[7,8]$; therefore, the present paper attempts to valorise $S$. sodomaeum in relation to its contents of fatty acids and essential oil. According to our bibliographic investigation, the current study could be the first report on the variation of the fatty acid and essential oil compositions of S. sodomaeum fruits according to the maturation stage, as well as evaluation of the antibacterial properties of the essential oil and the antioxidant properties of both essential and vegetal oils.

\section{MATERIAL AND METHODS}

\section{Plant material}

S. sodomaeum fruits were arbitrarily harvested from several individual plants in Borj-Cédria (HammamLif, northeast of Tunisia, $36^{\circ} 3^{\prime} 48^{\prime \prime} \mathrm{N}, 0^{\circ} 21^{\prime} 0^{\prime \prime} \mathrm{E}$ ) in the months of January and February 2012. Samples were collected at two phases of maturation on the basis of their colour. Full green fruits represented the immature stage and yellow ones, the mature stage. The harvested S. sodomaeum fruits were freezedried, powdered by using an electric mill and were preserved in a desiccator at ambient temperature $\left(25^{\circ} \mathrm{C}\right)$ in darkness. A voucher specimen was stored at the Herbarium of the Laboratory of Aromatic and Medicinal Plants at the Centre of Biotechnology of Borj-Cédria (Hammam-Lif, Tunisia) under the number SS-2012-07.

\section{Extraction and analysis of fatty acids}

By using the slightly modified procedure of Bligh and Dyer [8], lipids of triplicate sub-samples $(1 \mathrm{~g})$ of S. sodomaeum fruits were extracted. Briefly, samples were kept in boiling water for $5 \mathrm{~min}$, then ground with a mixture of chloroform-methanol-hexane 
$(2: 1: 1, \mathrm{v} / \mathrm{v} / \mathrm{v})$ and washed using the fixing water. The organic layer including lipids was recovered and dried using a nitrogen stream. Total fatty acids (TFAs) were trans-methylated by using sodium methylate solution (3\%) according to the procedure of Cecchi et al. [9]. Methyl heptadecanoate (C17:0) was used as an internal standard.

The resulting fatty acid methyl esters (FAMEs) were analysed using a Hewlett-Packard (HP) 6890 gas chromatograph series II (Agilent Technologies, Palo Alto, CA, USA) supplied with a flame ionisation detector (FID) and an electronic pressure control (EPC) injector. Separation of individual constituents was made by using a polar HP INNOWax capillary column $(30 \mathrm{~m} \times 0.25 \mathrm{~mm}$, coated with polyethylene glycol film of $0.25 \mu \mathrm{m}$ thickness; HewlettPackard, Palo Alto, CA, USA). The temperature of the oven was set at $150^{\circ} \mathrm{C}$ for $1 \mathrm{~min}$, elevated to $200^{\circ} \mathrm{C}$ at the rate of $15^{\circ} \mathrm{C} / \mathrm{min}$, maintained for $3 \mathrm{~min}$ and finally increased to $242^{\circ} \mathrm{C}$ at a rate of $2^{\circ} \mathrm{C} / \mathrm{min}$. The carrier gas was nitrogen with a flow rate of $1.5 \mathrm{ml} / \mathrm{min}$, and the split ratio was $60: 1$. Temperatures were set at $250^{\circ} \mathrm{C}$ and $275^{\circ} \mathrm{C}$ for the injector and detector, respectively. Identification of FAMEs was performed by comparing their retention times with those of the co-injected authentic standards.

\section{Isolation and analysis of essential oil}

Hydro-distillation of S. sodomaeum fruits (100 g) at each stage of maturation was made by using a Clevenger-type apparatus for $3 \mathrm{~h}$. Essential oils were dried over anhydrous sodium sulphate and stored at $4^{\circ} \mathrm{C}$ until analysis.

An aliquot $(0.5 \mu \mathrm{l})$ of each essential oil sample was analysed using gas chromatography-mass spectrometry (GC-MS). The GC analysis was performed by using a HP-5890 Series II instrument equipped with HP-INNOWax and HP-5 capillary columns ( $30 \mathrm{~m} \times 0.25 \mathrm{~mm}, 0.25 \mu \mathrm{m}$ film thickness for both). The temperature programme was as follows: the initial oven temperature was set at $60^{\circ} \mathrm{C}$ for $10 \mathrm{~min}$, then raised to $220^{\circ} \mathrm{C}$ at the rate of $5^{\circ} \mathrm{C} / \mathrm{min}$. The temperatures of the injector and the detector were set at $250^{\circ} \mathrm{C}$. Nitrogen was the carrier gas, with a flow rate of $2 \mathrm{ml} / \mathrm{min}$, the detector was dual FID and the split ratio was 1:30. The FID peak area normalisation yielded the percentages of the essential oil constituents. GC-MS analyses were conducted using a Varian CP3800 gas chromatograph equipped with a HP-5 capillary column $(30 \mathrm{~m} \times 0.25 \mathrm{~mm}$; coating thickness: $0.25 \mu \mathrm{m}$ ) and a Varian Saturn 2000 iontrap mass spectrometer. The injector and transfer line temperatures were $220^{\circ} \mathrm{C}$ and $240^{\circ} \mathrm{C}$, respectively. The temperature of the oven was raised from $60^{\circ} \mathrm{C}$ to $240^{\circ} \mathrm{C}$ at $3^{\circ} \mathrm{C} / \mathrm{min}$. Helium was the carrier gas, with a flow rate of $1 \mathrm{ml} / \mathrm{min}$. The split ratio was 1:30. The essential oil constituents were identified by comparison of their retention times with those of authentic samples, by comparing their linear indices relative to a series of $\mathrm{n}$-hydrocarbons and by computer conformity with commercial standards (National Institute of Standards and Technology, 1999). In addition, identification was achieved using a homemade library of mass spectra built up from pure substances and components of known oils and mass spectra literature data [10-11]. Furthermore, GC-chemical ionisation MS (CIMS) permitted the confirmation of molecular weights of all identified substances, using methanol as CI ionizing gas.

\section{Screening of antibacterial activity}

The disc diffusion method was adopted to evaluate the antibacterial activity [13] against several human pathogenic bacteria, namely, Bacillus cereus ATCC 10876, methicillin-resistant Staphylococcus aureus ATCC 25922, Listeria monocytogenes ATCC 15313, Salmonella DMS 560 and Pseudomonas aeruginosa ATCC 27853. All bacteria were grown on MuellerHinton plate at $30^{\circ} \mathrm{C}$ for $18-24 \mathrm{~h}$ before inoculation into the nutrient agar. A loop of bacteria from the agar slant stock was cultivated in nutrient broth overnight; a sample of this culture was streaked with a sterile cotton swab onto Petri dishes containing $10 \mathrm{ml}$ of API suspension medium and adjusted to the $0.5 \mathrm{McF}$ arland turbidity standards with a Densimat (BioMerieux). Sterile filter paper discs (6 mm diameter) soaked in essential oils of $S$. sodomaeum fruits were put on the culture plates. After $1-2 \mathrm{~h}$ at $4^{\circ} \mathrm{C}$, the treated Petri dishes were incubated at $25^{\circ} \mathrm{C}$ or $37^{\circ} \mathrm{C}$ for $18-24 \mathrm{~h}$. Tetracycline was used as the positive control. The antimicrobial activity was assessed by measuring the diameter of the growth inhibition zone surrounding the discs. Triplicates of each experiment were performed.

\section{1,1-Diphenyl-2-picryl-hydrazyl radical (DPPH•)-scavenging activity}

The activity of S. sodomaeum samples against free radicals was evaluated according to the procedure of Hanato et al. [14]. Accordingly, $0.5 \mathrm{ml}$ of a methanolic solution of DPPH $(0.2 \mathrm{mM})$ was added to the essential oil and vegetal oil of $S$. sodomaeum fruits. 
The mixture was incubated for $30 \mathrm{~min}$ at room temperature, and the absorbance was read against a blank at $517 \mathrm{~nm}$; the positive control was butylated hydroxytoluene (BHT).

The equation adopted to assess the inhibition percentage (I\%) of DPPH free radical was as follows:

$\mathrm{I} \%=\left[\left(\mathrm{A}_{0}-\mathrm{A}_{1}\right) / \mathrm{A}_{0}\right] \times 100$,

where $A_{0}$ is the absorbance of the control and $A_{1}$ is the absorbance of the samples in the mixture.

\section{Reducing power assay}

The procedure proposed by Oyaizu [15] was used to evaluate the reducing power of $S$. sodomaeum samples. Thus, $1 \mathrm{ml}$ of essential oil or vegetal oil was added to $2.5 \mathrm{ml}$ of a solution of sodium phosphate buffer (0.2 M, pH 6.6) and a solution of potassium ferricyanide $(2.5 \mathrm{ml}$ of $1 \%$ solution $)$. The mixture was incubated in a water bath at $50^{\circ} \mathrm{C}$ for $20 \mathrm{~min}$. Subsequently, $2.5 \mathrm{ml}$ of $10 \%$ trichloroacetic acid was added, and the mixture was submitted to centrifugation at $650 \mathrm{~g}$ for $10 \mathrm{~min}$. Thereafter, $2.5 \mathrm{ml}$ of distilled water and $0.5 \mathrm{ml}$ of a solution of iron (III) chloride $(0.1 \%)$ were mixed with $2.5 \mathrm{ml}$ of supernatant. The absorbance was read at $700 \mathrm{~nm}$, and vitamin $\mathrm{C}$ was adopted as the positive control.

\section{Statistical analysis}

Results were expressed as mean values \pm standard deviation of triplicates. Differences between groups were analysed by analysis of variance (ANOVA) procedure, and significant $(p<0.05)$ differences were evaluated according to Duncan's multiple-range test.

Ethical approval: The conducted research is not related to either human or animal use.

\section{RESULTS AND DISCUSSION}

\section{Total lipids and fatty acid constituents}

Total lipids and percentages of the identified fatty acids of S. sodomaeum fruits at the two phases of maturation are shown in Table 1 . The level of total

Table 1.

Variations in total lipid contents and fatty acid compositions during the maturation process of Solanum sodomaeum fruits

\begin{tabular}{|c|c|c|}
\hline \multirow{2}{*}{ Parameters } & \multicolumn{2}{|c|}{ Maturation stage } \\
\hline & Immature fruits & Mature fruits \\
\hline Total lipid content $[\%, w / w]$ & $12 \%$ & $17 \%$ \\
\hline C 12:0 & $0.48 \pm 0.31 \mathrm{a}$ & $0.46 \pm 0.12 \mathrm{a}$ \\
\hline C 14:0 & $1.32 \pm 0.56 \mathrm{a}$ & $0.86 \pm 0.35 \mathrm{a}$ \\
\hline C 16:0 & $21.96 \pm 1.60 \mathrm{a}$ & $15.63 \pm 1.17 \mathrm{~b}$ \\
\hline C $16: 1$ & $0.34 \pm 0.01 \mathrm{a}$ & $0.42 \pm 0.02 \mathrm{a}$ \\
\hline C $18: 0$ & $33.32 \pm 11.19 \mathrm{a}$ & $14.45 \pm 4.84 \mathrm{~b}$ \\
\hline C $18: 1$ & $5.06 \pm 2.07 \mathrm{~b}$ & $11.69 \pm 1.75 \mathrm{a}$ \\
\hline C $18: 2$ & $34.017 \pm 4.11 \mathrm{~b}$ & $53.11 \pm 7.89 \mathrm{a}$ \\
\hline C $18: 3$ & $1.75 \pm 0.58 \mathrm{a}$ & $0.76 \pm 0.11 \mathrm{~b}$ \\
\hline C $18: 4$ & $0.38 \pm 0.05$ & ND \\
\hline C $20: 0$ & $1.01 \pm 0.24 \mathrm{a}$ & $0.54 \pm 0.18 \mathrm{~b}$ \\
\hline C $20: 1$ & $0.26 \pm 0.07 \mathrm{a}$ & $0.64 \pm 0.60 \mathrm{a}$ \\
\hline C 22:0 & $0.44 \pm 0.03 \mathrm{~b}$ & $1.09 \pm 0.26 \mathrm{a}$ \\
\hline C $22: 1$ & $0.33 \pm 0.13 \mathrm{~b}$ & $0.53 \pm 0.13 \mathrm{a}$ \\
\hline Saturated fatty acids & 58.52 & 33.03 \\
\hline Monounsaturated fatty acids & 6.01 & 13.28 \\
\hline Polyunsaturated fatty acids & 36.30 & 53.87 \\
\hline
\end{tabular}

Compounds are listed in order of their elution in the HP-INNOWax column; values are represented as mean values \pm standard deviation of three independent replicates $(n=3)$; values followed by the same letter did not share significant differences at $5 \%$ (Duncan test); ND: not detected 
oil reached $12 \%$ in the immature stage (green fruits) and then sharply increased to $\sim 17 \%$ at the mature stage (yellow fruits). There are no investigations on the total lipid accumulation during the course of the maturation process of $S$. sodomaeum. Nevertheless, several researchers have focussed on the effect of the stage of maturation on the accumulation of lipids in diverse species. In accordance with our results, Glew et al. [16] demonstrated low accumulation of total lipids at an earlier stage of the development of date plum persimmon, while the level was enhanced quickly in the course of the last stage. The same behaviour was also observed in juçara (Euterpe edulis Martius) fruits [17] and Rhus tripartitum fruits [18].

To our knowledge, the current study is the first investigation on fatty acid accumulation in S. sodomaeum fruits. Totally, 13 fatty acids were determined in the vegetal oils. The fatty acid profiles were qualitatively similar, but they displayed significant $(p<0.05)$ quantitative differences, in particular for the most abundant constituents, according to the maturation phase (tab. 1). In the immature phase, the vegetal oils of the $S$. sodomaeum fruit were defined by the preponderance of saturated fatty acids (SFA), with a level of $58.52 \%$ of TFAs. The latter fraction is mainly represented by stearic acid (C18:0; $33.32 \%)$ and palmitic acid (C16:0; $21.96 \%)$. In addition, linoleic acid $(\mathrm{C} 18: 2 ; 34.17 \%)$ was detected as one of the most abundant fatty acids in immature fruits, and it increased considerably to reach the level of $53.11 \%$ at the mature stage. Linoleic acid accumulation could be explained by the activity of the $\Delta 12$-desaturase, a membrane-bound enzyme, which ensures the desaturation of oleic to linoleic acid [19]. It is an essential fatty acid for humans, and it is preferentially used in industries for hydrogenation of oils [20]. In addition, S. sodomaeum fruits showed a more-than-twofold increase in the level of oleic acid $(\mathrm{C} 18: 1 ; 11.69 \%)$ and a significant $(p<0.05)$ reduction in the contents of stearic $(\mathrm{C} 18: 0 ; 14.45 \%)$ and palmitic $(\mathrm{C} 16: 0 ; 15.63 \%)$ acids at the mature phase. The unsaturated fatty acid fraction was the most abundant fraction $(67.15 \%)$ of the fruits' vegetal oil, in particular, polyunsaturated fatty acids (PUFAs) were highly represented (53.87\%). It is worth noting that increased attention to PUFA as healthy components in the diet is due to their multiple benefits such as their role in relieving cardiovascular, inflammatory and heart disorders, atherosclerosis, autoimmune disease, diabetes and other health issues [21]. Furthermore, palmitic acid could cause several damages, such as oxidative DNA damage, human cell necrosis and apoptosis. These damages could be repressed by consuming - in parallel - other fatty acids, in particular PUFAs [22]. In regard to the context of the fatty acid contents, mature fruits seemed to be healthier since they contained higher percentages of PUFA and lower content of palmitic acid.

\section{Essential oil composition}

The essential oil yields of $S$. sodomaeum fruits ranged from $0.43 \%$ for immature fruits to $0.45 \%$ for mature fruits $(\mathrm{v} / \mathrm{w})$, and the differences in yield between the stages of maturation were not significant $(p>0.05)$.

The composition of the essential oils of the S. sodomaeum fruits at two different maturation stages is illustrated in table 2 . Thirty components were identified, with percentages of $99.61 \%$ and $95.10 \%$ of the total oil, respectively, for immature and mature fruits. The stage of immature fruits showed tetrahydronaphthalene $(41.79 \%)$ as the major constituent of the essential oils. Considerable percentages of hexadecanoic acid (24.15\%), dihydrocoumarin pentane $(8.23 \%)$, tridecanone $(3.61 \%)$ and 2-undecanone $(2.69 \%)$ were also detected. Dihydrocoumarin pentane, hexadecanoic acid and 2-undecanone were found to be the most abundant components of essential oils of $S$. sodomaeum mature fruits, with the percentages of $18.27 \%, 17.43 \%$ and $13.20 \%$, respectively.

On the whole, acenes were the most abundant chemical group at the immature stage (43.47\%), and their percentages showed a substantial decrease at the mature stage $(7.93 \%)$. Conversely, ketones $(20.65 \%)$, aldehydes $(9.32 \%)$, sesquiterpenes (5.12\%), alcohols (10.28\%) and esters (1.76\%) were characterised by a significant $(p<0.05)$ augmentation of their values at the mature phase.

It is worth noting that the ketone fraction, in particular, 2-undecanone and tridecanone, have been widely reported to be toxic for several arthropod pests [23]. Also, hexadecanoic acid, a monocarboxylic acid, contributes to the aromatic character of several plants. This acid has been evaluated for inducing resistance in crop plants, such as tomato, against Botrytis cinerea [24], and citrus, against the fungus Alternaria alternata [25]. Aldehydes are reported to be responsible of the floral and fruity aroma of citrus [26]. It must be taken into consideration that the components in lower amounts, such as $\alpha$-pinene, $\beta$-pinene, $\mathrm{D}$-limonene, camphene, $\mathrm{p}$ cymene and $\beta$-thujone, contribute to the antifungal property of the essential oils, as previously demonstrated by Sacchetti et al. [27]. Additionally, the 
Table 2

Variations in the essential oil composition [\% total peak area] at the two stages of maturation of Solanum sodomaeum fruits

\begin{tabular}{|c|c|c|c|}
\hline Components & IR & Immature fruits & Mature fruits \\
\hline$\alpha$-Pinene & 935 & $0.54 \pm 0.13$ & ND \\
\hline Camphene & 951 & $0.40 \pm 0.08$ & ND \\
\hline$\beta$-Pinene & 980 & ND & $0.54 \pm 0.06$ \\
\hline p-Cymene & 1023 & $0.29 \pm 0.06$ & ND \\
\hline D-Limonene & 1027 & $1.11 \pm 0.13 \mathrm{~b}$ & $1.39 \pm 0.16 \mathrm{a}$ \\
\hline 2, 6-Dimethyl-5-heptenal & 1053 & $1.39 \pm 0.52 \mathrm{~b}$ & $3.83 \pm 1.03 \mathrm{a}$ \\
\hline 2-Nonanone & 1094 & $0.26 \pm 0.03$ & ND \\
\hline$\beta$-Thujone & 1107 & $0.73 \pm 0.14 \mathrm{a}$ & $0.57 \pm 0.29 \mathrm{a}$ \\
\hline Camphor & 1142 & $0.66 \pm 0.12$ & ND \\
\hline Decanal & 1206 & $0.51 \pm 0.18 b$ & $1.24 \pm 0.14 \mathrm{a}$ \\
\hline 1-Decanol & 1269 & $1.50 \pm 0.55 \mathrm{~b}$ & $3.93 \pm 0.91 \mathrm{a}$ \\
\hline Undecanal & 1290 & $0.73 \pm 0.24 \mathrm{~b}$ & $1.88 \pm 0.31 \mathrm{a}$ \\
\hline 2-Undecanone & 1295 & $2.69 \pm 0.39 \mathrm{~b}$ & $13.20 \pm 1.32 \mathrm{a}$ \\
\hline Carvacrol & 1303 & $2.01 \pm 0.15 \mathrm{a}$ & $2.41 \pm 0.39 \mathrm{a}$ \\
\hline Dodecanal & 1410 & $1.51 \pm 0.23$ & ND \\
\hline Caryophyllene & 1428 & $0.92 \pm 0.19 \mathrm{~b}$ & $1.46 \pm 0.17 \mathrm{a}$ \\
\hline Pentadecanone & 1454 & $0.83 \pm 0.20 \mathrm{~b}$ & $2.55 \pm 0.15 \mathrm{a}$ \\
\hline Dihydrocoumarin pentane & 1486 & $8.23 \pm 1.88 \mathrm{~b}$ & $18.27 \pm 1.90 \mathrm{a}$ \\
\hline Tridecanone & 1497 & $3.61 \pm 0.49 \mathrm{a}$ & $4.33 \pm 0.38 \mathrm{a}$ \\
\hline 1-Tridecanol & 1553 & $0.38 \pm 0.09 \mathrm{~b}$ & $1.00 \pm 0.17 \mathrm{a}$ \\
\hline Z-3-Hexenyl benzoate & 1564 & $0.50 \pm 0.13 \mathrm{~b}$ & $1.76 \pm 0.18 \mathrm{a}$ \\
\hline Caryophyllene alcohol & 1572 & $0.48 \pm 0.10 \mathrm{~b}$ & $1.19 \pm 0.34 \mathrm{a}$ \\
\hline Humulene oxide & 1607 & $1.00 \pm 0.11 \mathrm{~b}$ & $2.19 \pm 0.47 \mathrm{a}$ \\
\hline Tetradecanal & 1621 & $0.56 \pm 0.12 \mathrm{~b}$ & $1.22 \pm 0.30 \mathrm{a}$ \\
\hline Pentadecanal & 1719 & ND & $1.15 \pm 0.03$ \\
\hline Trimethyl hexanol & 1820 & $0.51 \pm 0.12 \mathrm{~b}$ & $4.17 \pm 0.66 \mathrm{a}$ \\
\hline 7,11,15-Trimethyl neophytadiene & 1837 & $1.68 \pm 0.42 \mathrm{a}$ & $1.58 \pm 0.33 \mathrm{a}$ \\
\hline Cyclopropanaphthalene & 1919 & $0.67 \pm 0.12 \mathrm{~b}$ & $1.59 \pm 0.12 \mathrm{a}$ \\
\hline Tetrahydronaphthalene & 1920 & $41.79 \pm 5.58 \mathrm{a}$ & $6.36 \pm 0.96 \mathrm{~b}$ \\
\hline Hexadecanoic acid & 1965 & $24.15 \pm 9.11 \mathrm{a}$ & $17.43 \pm 1.63 \mathrm{a}$ \\
\hline Total & $99.61 \pm 1.46 \mathrm{a}$ & $95.10 \pm 5.33 \mathrm{a}$ & \\
\hline \multicolumn{4}{|c|}{ Chemical classes [\%] } \\
\hline Acenes & - & $43.47 \pm 5.84 \mathrm{a}$ & $7.93 \pm 0.78 \mathrm{~b}$ \\
\hline Acids & - & $24.15 \pm 9.11 \mathrm{a}$ & $17.43 \pm 1.63 \mathrm{a}$ \\
\hline Phenols & - & $2.01 \pm 0.15 \mathrm{a}$ & $2.41 \pm 0.39 \mathrm{a}$ \\
\hline Ketones & - & $8.78 \pm 0.79 \mathrm{~b}$ & $20.65 \pm 2.06 \mathrm{a}$ \\
\hline Aldehydes & - & $4.70 \pm 1.04 \mathrm{~b}$ & $9.32 \pm 1.56 \mathrm{a}$ \\
\hline Monoterpenes & - & $2.34 \pm 0.40 \mathrm{a}$ & $1.93 \pm 0.17 \mathrm{a}$ \\
\hline Sesquiterpenes & - & $2.59 \pm 0.41 \mathrm{~b}$ & $5.12 \pm 0.50 \mathrm{a}$ \\
\hline Alcohols & - & $2.86 \pm 0.58 \mathrm{~b}$ & $10.28 \pm 0.91 \mathrm{a}$ \\
\hline Esters & - & $0.50 \pm 0.13 \mathrm{~b}$ & $1.76 \pm 0.18 \mathrm{a}$ \\
\hline Others & - & $8.23 \pm 1.88 \mathrm{~b}$ & $18.27 \pm 1.90 \mathrm{a}$ \\
\hline
\end{tabular}

Compounds are listed in the order of their elution on a HP-INNOWax column; values followed by the same letter did not share significant differences at 5\% (Duncan test); ND: not detected; values are represented as mean values \pm standard deviation of three independent replicates. 
minor components might contribute to some type of synergism with other different bioactive components [28].

According to our bibliographic investigation, there is no previous survey on the variation of the chemical composition of essential oils of S. sodomaeum during fruit maturation. Nevertheless, such studies have been undertaken for several medicinal and aromatic plants, which showed significant changes in the composition of the oils according to the maturation phase. These changes could be due to variations in climatic conditions, such as temperature, relative humidity, sunshine hours and precipitations [29], and may be associated with metabolic changes that precede the process of and prepare the fruit for maturation.

\section{Antioxidant activity}

The evaluation of the total antioxidant property of S. sodomaeum fruits cannot be estimated by using a single method, because of the variety of phytochemicals and the related chemical moieties [30]. So, in the present study, two methods - including DPPH test and reducing power assay - were used to assess the antioxidant activity of the essential oil and vegetal oil of immature and mature fruits.

Results of the DPPH radical scavenging and reducing power tests are given in Figure 1. As shown in Figure 1a, the oils of $S$. sodomaeum fruits at the two maturation phases revealed much lower capacity to reduce the DPPH radical to the yellowcoloured diphenylpicrylhydrazine, as compared with BHT $\left(\mathrm{IC}_{50}=10.77 \mu \mathrm{g} / \mathrm{ml}\right)$. The best activities were observed for the essential oils with no significant differences $(p>0.05)$ in levels between the immature $\left(\mathrm{IC}_{50}=6.73 \mathrm{mg} / \mathrm{ml}\right)$ and mature $\left(\mathrm{IC}_{50}=\right.$ $6.71 \mathrm{mg} / \mathrm{ml}$ ) stages of the fruits. Lower DPPH-scavenging activities were detected for vegetal oils in the immature $\left(\mathrm{IC}_{50}=28.50 \mathrm{mg} / \mathrm{ml}\right)$ and mature $\left(\mathrm{IC}_{50}=\right.$ $28.47 \mathrm{mg} / \mathrm{ml}$ ) phases of the fruits.

Reducing power is evaluated based on the measurement of the conversion of ferric iron ( $\mathrm{Fe} 3 \mathrm{p})$ to ferrous iron $(\mathrm{Fe} 2 \mathrm{p})$ in the presence of antioxidants [31]. Contrary to results obtained for the DPPH assay (fig. 1b), the reducing power test showed higher antioxidant activity for vegetal oils with significant differences $(p<0.05)$ in levels between the two stages of fruit maturation. The immature fruits $\left(\mathrm{EC}_{50}=3.75 \mathrm{mg} / \mathrm{ml}\right)$ revealed better reducing power compared with the mature ones $\left(\mathrm{EC}_{50}=16.93 \mathrm{mg} / \mathrm{ml}\right)$ and vitamin $\mathrm{C}\left(\mathrm{EC}_{50}=8.33 \mathrm{mg} / \mathrm{ml}\right)$.

Previous investigations have suggested that there is an association between chemical composition and antioxidant activity. In accordance with the study by Hazzit et al. [33], the antioxidant capacity of essential oils could be ascribed to the phenolic components in plant oils, particularly thymol and/or carvacrol. In coherence with the current study, the

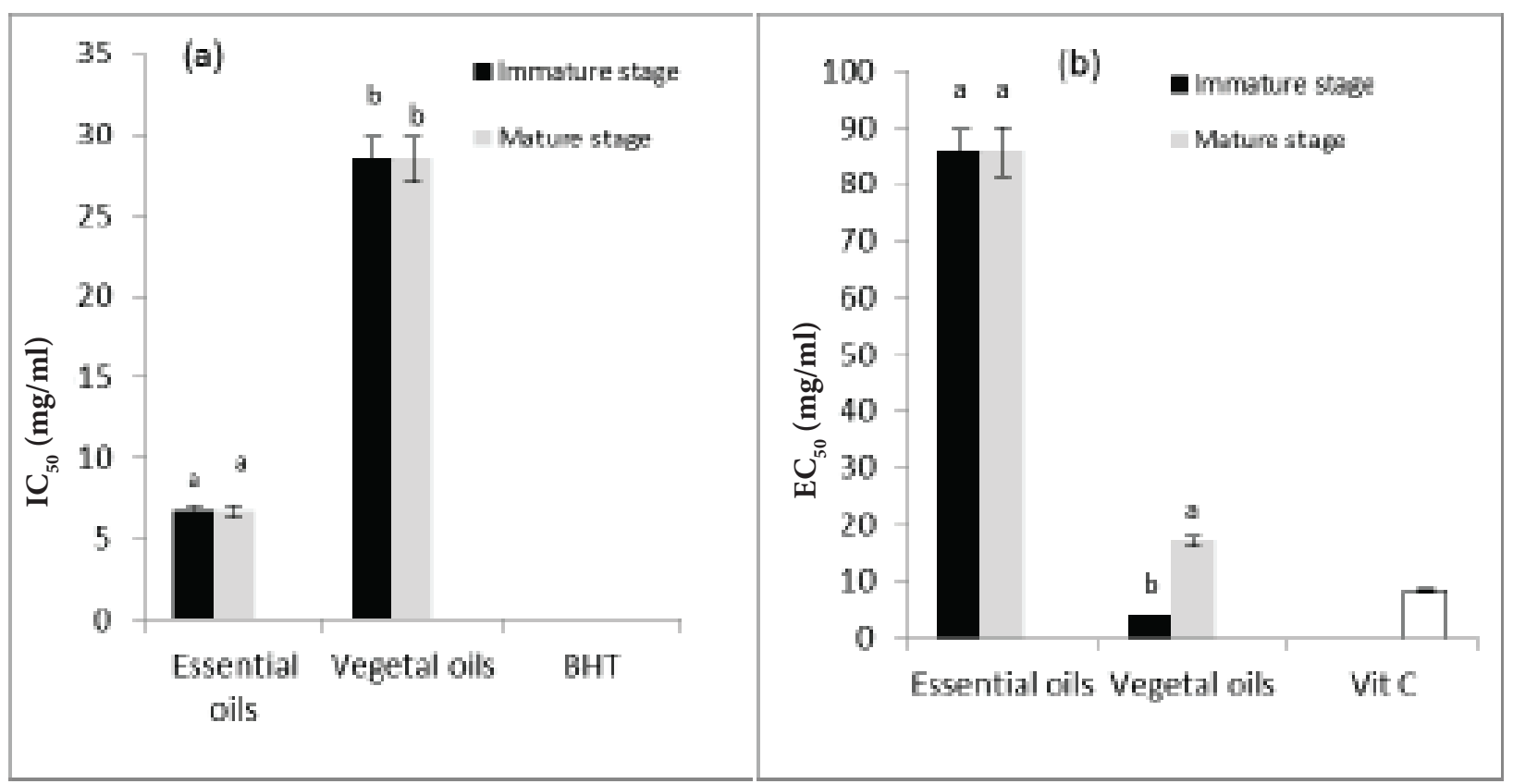

Figure 1.

Antioxidant activity measured by the DPPH scavenging (a) and reducing power (b) assays at the immature and mature fruit stages. Data are represented as mean values \pm standard deviation of three independent replicates. Bars sharing the same small letter did not share significant differences at $p<0.05$ (Duncan test) 
moderate antioxidant capacity could be due to the low amounts of phenolic and terpenic compounds. However, it is worth noting that the antioxidant activity of the essential oils is not ascribed exclusively to the highly represented compounds and minor ones also could be implied in the total antioxidant activity; moreover, synergistic effects have also been described [33]. In addition, previous investigations have demonstrated that the antioxidant capacities of vegetal oils could be attributed in most part to PUFAs, tocopherols and phenolics [34, 35].

According to our bibliographic research, there is no previous investigation available regarding the antioxidant activities of $S$. sodomaeum essential oil and vegetal oil with respect to fruit maturation stages.

\section{Antibacterial activity}

Several essential oils and extracts from various plant species have been shown to be capable of inhibiting microorganisms in the contexts of skin infection, dental caries and food spoilage. The antimicrobial capacity of most essential oils or plant extracts is substantially less effective than that of synthetic antibiotics. However, they have diverse modes of action and, therefore, may be able to combat the resistant strains of microorganisms [36].

Results of the antibacterial activity analysis of the essential oils of $S$. sodomaeum fruits at two maturation phases against three Gram-positive bacteria (B. cereus, L. monocytogenes and S. aureus) and two Gram-negative bacteria (P. aeruginosa and Salmonella DMS 560) are illustrated in table 3.

The essential oil of immature fruits showed inhibitory activity against Salmonella $(2.5 \mathrm{~mm})$ which was lower by more than ten times than the activity of the control tetracycline $(27.0 \mathrm{~mm})$. The essential oil of mature fruits was more efficient than that of immature ones, since the growth inhibition of $P$. aeruginosa, B. cereus, L. monocytogenes and
S. aureus was only observed for the oils extracted at the mature phase. Moreover, it is worth noting that the Gram-positive bacteria were more sensitive than Gram-negative ones to the essential oils (tab. 3). Previously, some investigations have demonstrated that Gram-negative bacteria were resistant to the effects of essential oil and its constituents [37]. The resistance has been ascribed to the existence of cell wall lipopolysaccharides that can screen out the essential oil [38].

Essential oils are a mixture of a variety of major and minor chemical components. Along with major components, previous investigations have reported that the less representative components and a potential interaction between the constituents could also influence the antimicrobial activities [37].

Results of the current study support the use of essential oils from the mature fruits of $S$. sodomaeum in the treatment of diseases caused by the tested bacteria, because of the natural origin of the remedy, the safety for the consumers and the low risk of development of resistance by pathogenic microorganisms [39].

\section{CONCLUSION}

The overall results permitted the valorisation of $S$. sodomaeum fruits for their antioxidant and antibacterial properties, which might lead to their potential use as nutraceuticals and agro-food supplements.

Conflict of interest: Authors declare no conflict of interest.

\section{REFERENCES}

1. Al Sinani SSS, Eltayeb EA. The steroidal glycoalkaloids solamargine and solasonine in Solanum plants. S Afr J Bot 2017; 112:253-69. doi: http:// dx.doi.org/10.1016/j.sajb.2017.06.002

Table 3

Antibacterial activity of essential oils of Solanum sodomaeum fruits against three Gram-positive and two Gram-negative bacteria

\begin{tabular}{|c|c|c|c|}
\hline \multirow{2}{*}{ Bacteria species } & \multicolumn{2}{|c|}{ Maturation stage } & \multirow[b]{2}{*}{ Tetracycline } \\
\hline & Immature & Mature & \\
\hline Pseudomonas aeruginosa & - & $8.5 \pm 1.0$ & 23.0 \\
\hline Salmonella DMS 560 & $2.5 \pm 1.0$ & $7.5 \pm 1.0$ & 27.0 \\
\hline Bacillus cereus & - & $16.0 \pm 2.0$ & 22.0 \\
\hline Listeria monocytogenes & - & $18.5 \pm 1.0$ & 36.0 \\
\hline Staphyloccun aureus ATCC 25922 & - & $20.5 \pm 1.0$ & 35.0 \\
\hline
\end{tabular}

(-) absence of activity; the diameter of inhibition is measured in millimetres; experiments were done in triplicate. 
2. Lee MH, Cheng JJ, Lin CY, Chen YJ, Lu MK. Precursor-feeding strategy for the production of solanine, solanidine and solasodine by a cell culture of Solanum lyratum. Process Biochem 2007; 42:899-903. doi: http://dx.doi.org/10.1016/j.procbio.2007.01.010

3. Maurya A, Gupta S, Negi S, Srivastava SK. pHzone-refining centrifugal partition chromatography for preparative isolation and purification of steroidal glycoalkaloids from Solanum xanthocarpum. J Sep Sci 2009; 32:3126-32. doi: http:// dx.doi.org/10.1002/jssc.200900323

4. Friedman M. Analysis of biologically active compounds in potatoes (Solanum tuberosum), tomatoes (Lycopersicon esculentum) and jimson weed (Datura stramonium) seeds. J Chromatogr A 2005; 1054:143-55. doi: http://dx.doi. org/10.1016/j.chroma.2004.04.049

5. Jouzier E. Solanacées médicinales et philatélie. Bull Soc Pharm Bordeaux 2005; 144:311-32.

6. Cham BE, Meares HM. Glycoalcaloids from Solanum sodomaeum are effective in the treatment of skin cancers in man. Cancer Lett 1987; 36:111-8. doi: http://dx.doi.org/10.1016/03043835(87)90081-4

7. Ono M, Nishimura K, Suzuki K, Fukushima T, Igoshi K, Yoshimitsu $\mathrm{H}$ et al. Steroidal glycosides from the underground parts of Solanum sodomaeum. Chem Pharm Bull 2006; 54(2):230-3. doi: http://dx.doi.org/10.1002/chin.200628178

8. Bligh EG, Dyer WJ. A rapid method of total lipid extraction and purification. Can J Biochem Phys 1959; 37:911-7. doi: http://dx.doi.org/10.1139/ 059-099

9. Cecchi G, Biasini S, Castano J. Methanolyse rapide des huiles en solvant. Note de laboratoire. Rev Fr Corps Gras 1985; 4:163-164.

10. Lafferty FW, Stauffer DB. Wiley registry of mass spectral data. 6th ed. Mass Spectrometry Library Search System Bench-Top/PBM, Version 3.10d. Newfield, UK. Palisade, 1994.

11. Adams RP. Identification of essential oil components by gas chromatography/mass spectrometry. 4th ed. Carol Stream, IL. Allured Publishing Corporation, 2007.
12. König WA, Hochmuth DH, Joulain D. Terpenoids and related constituents of essential oils. Hamburg. Library of Mass Finder, Institute of Organic Chemistry, 2001.

13. Rios JL, Recio MC. Medicinal plants and antimicrobial activity. J Ethnopharmacol 2005; 100:80-4. doi: http://dx.doi.org/10.1016/j.jep.2005.04.025

14. Hanato T, Kagawa H, Yasuhara T, Okuda T. Two new flavonoids and other constituents in licorice root: their relative astringency and radical scavenging effect. Chem Pharm Bull 1988; 36:10901097. doi: http://dx.doi.org/10.1248/cpb.36.2090

15. Oyaizu M. Studies on products of browning reaction: antioxidative activity of products of browning reaction. Jpn J Nutr Diet 1986; 44:307315. doi: http://dx.doi.org/10.5264/eiyogakuzashi.44.307

16. Glew RH, Ayaz FA, Millson M, Huang HS, Chuang LT, Sanz C et al. Changes in sugars, acids and fatty acids in naturally parthenocarpic date plum persimmon (Diospyros lotus L.) fruit during maturation and ripening. Eur J Lipid Sci Technol 2005; 221:113-118. doi: http://dx.doi. org/10.1007/s00217-005-1201-9

17. Schulz M, Borges GSC, Gonzaga LV, Seraglio Olivo SKT, Azevedo IS, Nehring P et al. Chemical composition, bioactive compounds and antioxidant capacity of juçara fruit (Euterpe edulis Martius) during ripening. Food Res Int 2015; 77:125-131. doi: http://dx.doi.org/10.1016/j. foodres.2015.08.006

18. Tlili N, Tir M, Benlajnef H, Khemiri S, Mejri H, Rejeb $S$ et al. Variation in protein and oil content and fatty acid composition of Rhus tripartitum fruits collected at different maturity stages in different locations. Ind Crops Prod 2014; 59:197-201. doi: http://dx.doi.org/10.1016/j.indcrop.2014.05.020

19. El Arem A, Flamini G, Saafi EB, Issaoui M, Zayene N, Ferchichi A et al. Chemical and aroma volatile compositions of date palm (Phoenix dactylifera L.) fruits at three maturation stages. Food Chem 2011; 127:1744-1754. doi: http://dx.doi. org/10.1016/j.foodchem.2011.02.051

20. Msaâda K, Hosni K, Ben Taarit M, Chahed T, Hammami M, Marzouk B. Changes in fatty acid 
composition of coriander (Coriandrum sativum L.) fruit during maturation. Ind Crops Prod 2009; 29:269-274. doi: http://dx.doi.org/10.1016/j.indcrop.2008.05.011

21. Finley JW, Shahidi F. The chemistry, processing and health benefits of highly unsaturated fatty acids: an overview. In: John WJ, Shahidi F, eds. Omega-3 fatty acids, chemistry, nutrition and health effects. Washington. American Chemical Society, 2001:258-279.

22. Carvalho IS, Teixeira MC, Brodelius M. Fatty acids profile of selected Artemisia ssp. plants: health promotion. LWT Food Sci Technol 2011; 44:293-8. doi: http://dx.doi.org/10.1016/j. lwt.2010.05.033

23. Kauffman WC, Kennedy GG. Relationship between trichome density in tomato and parasitism of Heliothis spp. (Lepidoptera: Noctuidae) eggs by Trichogramma spp. (Hymenoptera: Trichogrammatidae). Environ Entomol 1989; 18:698-704. doi: http://dx.doi.org/10.1093/ee/18.4.698

24. Vicedo B, Flors V, Leyva MD, Finiti I, Kravchuk $\mathrm{Z}$, Real MD et al. Hexanoic acid-induced resistance against Botrytis cinerea in tomato plants. Mol Plant Microbe Interact 2009; 22:1455-65. doi: http://dx.doi.org/10.1094/MPMI-22-11-1455

25. Llorens E, Vicedo B, Lopez MM, Lapena L, Graham $\mathrm{JH}$, García-Agustín P. Induced resistance in sweet orange against Xanthomonas citri subsp. citri by hexanoic acid. Crop Prot 2015; 74:77-84. doi: http://dx.doi.org/10.1016/j.cropro.2015.04.008

26. Richard H. Connaissance de la nature des arômes. In: Richard H, Multon JL, eds. Les arômes alimentaires, Partie I, Généralités, Sciences et techniques agro-alimentaires. Paris. Lavoisier TEC and DOC-Apria, 1992.

27. Sacchetti G, Maietti S, Muzzoli MV, Scaglianti M, Manfredini S, Radice $M$ et al. Comparative evaluation of 11 essential oils of different origin as functional antioxidants, antiradicals and antimicrobials in foods. Food Chem 2005; 91:621-32. doi: http://dx.doi.org/10.1016/j.foodchem.2004.06.031

28. Marino M, Bersani C, Comi G. Impedance measurements to study the antimicrobial activity of essential oils from Lamiaceae and Compositae.
Int J Food Microbiol 2001; 67:187-95. doi: http:// dx.doi.org/10.1016/S0168-1605(01)00447-0

29. Dhouioui M, Boulila A, Chaabane H, Saïd Zina M, Casabianc H. Seasonal changes in essential oil composition of Aristolochia longa L. ssp. paucinervis Batt. (Aristolochiaceae) roots and its antimicrobial activity. Ind Crops Prod 2016; 83:301-6. doi: http://dx.doi.org/10.1016/j.indcrop.2016.01.025

30. Chu YH, Chang CL, Hsu HF. Flavonoid content of several vegetables and their antioxidant activity. J Sci Food Agric 2000; 80:561-5. doi: http://dx.doi.org/10.1002/ (SICI) 1097-0010(200004)80:5<561::AIDJSFA574>3.0.CO;2-\#

31. Zhang Y, Yang L, Zu Y, Chen X, Wang F, Liu F. Oxidative stability of sunflower oil supplemented with carnosic acid compared with synthetic antioxidants during accelerated storage. Food Chem 2010; 118(3):656-62. doi: http://dx.doi. org/10.1016/j.foodchem.2009.05.038

32. Omar KA, Shan L, Wang YL, Wang X. Stabilizing flaxseed oil with individual antioxidants and their mixtures. Eur J Lipid Sci Technol 2010; 112(9):1003-11. doi: http://dx.doi.org/10.1002/ ejlt.200900264.

33. Hazzit M, Baaliouamer A, Veríssimo AR, Faleiro ML, Miguel MG. Chemical composition and biological activities of Algerian Thymus oils. Food Chem 2009; 116:714-21. doi: http://dx.doi. org/10.1016/j.foodchem.2009.03.018

34. Peschel W, Sanchez-Rabaneda F, Diekmann W, Plescher A, Gaetzia A, Gartzia I et al. An industrial approach in the search of natural antioxidants from vegetable and fruit wastes. Food Chem 2006; 97:137-50. doi: http://dx.doi.org/10.1016/j. foodchem.2005.03.033

35. Fruhwirth GO, Wenzl T, El-Toukhy R, Wagner FS, Hermetter A. Fluorescence screening of antioxidant capacity in pumpkin seed oils and other natural oils. Eur J Lipid Sci Technol 2003; 105:26674. doi: http://dx.doi.org/10.1002/ejlt.200390055

36. Latif S, Anwar F. Aqueous enzymatic sesame oil and protein extraction. Food Chem 2011; 125:679-84. doi: http://dx.doi.org/10.1016/j. foodchem.2010.09.064 
37. Głoniak P, Łos R, Skalicka-Wozniak K, Widelski J, Burczyk J, Malm A. Activity of Crithmum maritimum L. (Apiaceae) against Gram-positive bacteria. Lublin. Annales Universitatis Mariae CurieSklodowska, 2006.

38. Dob T, Dahmane D, Benabdelkader T, Chelghoum C. Studies on the essential oil composition and antimicrobial activity of Thymus algeriensis Boisset Reut. Int J Aromather 2006; 16:95-100. doi: http://dx.doi.org/10.1016/j.ijat.2006.04.003
39. Kivrak I, Duru ME, Öztürk M, Mercan N, Harmandar M, Topçu G. Antioxidant, anticholinesterase and antimicrobial constituents from the essential oil and ethanol extract of Salvia potentillifolia. Food Chem 2009; 116:470-9. doi: http:// dx.doi.org/10.1016/j.foodchem.2009.02.069 